Itinéraires Itinéraires

Littérature, textes, cultures

2020-2 | 2020

Discours animal. Langages, interactions, représentations

\title{
Interlude 3
}

\section{(2)enEdition}

\section{Journals}

Édition électronique

URL : https://journals.openedition.org/itineraires/8707

DOI : 10.4000/itineraires.8707

ISSN : 2427-920X

Éditeur

Pléiade

Référence électronique

"Interlude 3 », Itinéraires [En ligne], 2020-2 | 2020, mis en ligne le 18 décembre 2020, consulté le 25 novembre 2021. URL : http://journals.openedition.org/itineraires/8707 ; DOI : https://doi.org/10.4000/ itineraires.8707

Ce document a été généré automatiquement le 25 novembre 2021.

\section{(9) $\odot \Theta \Theta$}

Itinéraires est mis à disposition selon les termes de la licence Creative Commons Attribution - Pas d'Utilisation Commerciale - Pas de Modification 4.0 International. 


\section{Interlude 3}

\section{Citation}

«Au début de toute chose, la sagesse et la connaissance appartenaient aux animaux, car Tirawa, La Voûte des Cieux, ne parlait pas directement aux humains. Il envoyait des animaux dire aux hommes qu'il se montrait au travers des animaux, et que les humains devaient apprendre des étoiles, du soleil, et de la lune.» Paroles attribuées au chef de la tribu pawnee Leetakots-Lesa, dans Patty Summers, Talking with the Animals, Charlottesville, Hampton Road, 1998, p. 11. Traduit par Laura Goudet.

\section{Vidéo : Mister Ed le cheval qui parle (série, 1961-1966)}

Ce média ne peut être affiché ici. Veuillez vous reporter à l'édition en ligne http:// journals.openedition.org/itineraires/8707

\section{Enregistrement : Téléréalité chez les balbuzards}

Ce média ne peut être affiché ici. Veuillez vous reporter à l'édition en ligne http:// 